\title{
Determination of Heavy Metals Contamination in Some Vegetables and Fruits Samples from the Market of Jagdalpur, Chhattisgarh State.
}

\author{
Miss Priyanka Salhotra ${ }^{1}$, Mrs. Rashmi Verma ${ }^{2}$ \\ ${ }^{I}$ Chemistry Department C.V. Raman University Kota, Bilaspur, Chhattisgarh \\ ${ }^{2}$ Assistant Professor Chemistry Department C.V. Raman University Kota, Bilaspur, Chhattisgarh
}

\begin{abstract}
This study has been conducted to determine the concentration of heavy metals lead ( $\mathrm{Pb})$, cadmium $(\mathrm{Cd})$, copper $(\mathrm{Cu})$ iron $(\mathrm{Fe})$, cobalt $(\mathrm{Co})$ in ten commonly used vegetables and fruits available in local market of jagdalpur. (Bastar) Comparing the results of heavy metals in vegetables and fruits by using Atomic Absorption Spectrometer, (Thermo scientific Pvt. Ltd. India Model No. AA 303) double beam with their respective natural level. Fe concentration varied considerably in spinach, tomato, cauliflower and lady finger are crossed permissible limits. Copper concentration in cauliflower, spinach, apple, grapes are below than the safe limit. Overall, this study indicates that the vegetables and fruits sample are contaminated by toxic heavy metals.

Keywords: Heavy metals, fruits, vegetables,
\end{abstract}

\section{Introduction}

Fruits and vegetables are widely used for culinary purpose. Fruits and vegetables are very important in human diet because of presence of vitamins and minerals salts. They contain water, calcium, iron, sulphur and potash (Sobukola et al.2010). They also act as neutralizing agents for acidic substances forming during digestion (Thompson and Kelly 1990). Therefore fruits and vegetables are very useful for the maintenance of health as a preventive treatment of various diseases (D' mello, 2003). The presence of heavy metals may have a negative influence on the quality of vegetables and fruits causing changes to their taste and smell.

The term "heavy metals" to any metallic elements that has a relative density greater than $4 \mathrm{~g} / \mathrm{cm} 3$. In the group of heavy metals one can distinguish both the element necessary for living organism and elements whose physiological role is unknown and those that are "neutral" for plants, animals and humans. Accumulation of heavy metals by vegetables and fruits may depend on plant species as well as temperature, moisture, organic matter, $\mathrm{Ph}$, nutrient availability and concentration of heavy metals. The total concentration of heavy metals in soil and water however varies from local to regional and further to continental level. The uptake and accumulation of $\mathrm{Cd}, \mathrm{Cr}, \mathrm{Fe}$ were higher during the summer due to high transpiration rate as compared to winters whereas $\mathrm{Cu}, \mathrm{Ni}, \mathrm{Pb}$ accumulated more in winter. Heavy metals exert toxic effect on soil. Metals are industrious natural contaminants, have long biological half lives and potential for accumulation in different body organs leading to unwanted side effect. Metal toxicity in plants is aggravated at higher temperature and low ph as it facilitates the mobility from roots to shoots hence results in the change of the diversity population size and over all activity of soil microbial communities. Heavy metals concentration may inhibit some vital plant processes i.e. photosynthesis, mitosis and $\mathrm{H}_{2} \mathrm{O}$ absorption. The consumption of heavy metal contaminated food can seriously deplete some essential nutrients in body that are further responsible for decreasing immunological defenses, growth retardation disabilities associated with malnutrition and high prevalence of upper gastrointestinal cancer rates.

[A] Study Area:

\section{Experimental Methodology}

The study was conducted around Jagdalpur city of Bastar district Chhattisgarh during March 2017. This is one of the tribal districts of the state. Location of city is between 19.107 degree north latitudes and 81.953 degree east longitude. The district is located in southern part of of Chhattisgarh situated at the height of $2000 \mathrm{~m}$ above plateau MSL Various small scale industries situated in this town. A large area around industries have less acess to clean water resources, so farmer use treated and untreated waste water for irrigation. The hypothesis behind the present study is that the irrigation with waste water transportation and marketing site of vegetables is contaminated environment may elevate the levels of heavy metals in vegetable through surface deposition

\section{[B] Sampling:}

The edible portions of vegetables i.e. tomato, cauliflower, lady finger, spinach that brought from near by villages of jagdalpur i.e. bakawand, pushpal, adawal, lohandiguda to Jagdalpur were collected from transport 
vehicles during march 2017 which were shifting the vegetable and fruits to local market. They were classified according to their common name and scientific name:

\begin{tabular}{|l|l|}
\hline Common name & Scientific name \\
\hline Vegetable commodity & Spinicia Oleracea \\
\hline Spinach & Tomato(Solanum lycoperiscum) \\
\hline Tomato & Abelmoschus Esculentus \\
\hline Lady finger & Brassica Oleracea Botrytis \\
\hline Cauliflower & Citrullus Lanatus thumb. \\
\hline Fruits commodity & Vitis Vinifera \\
\hline Water melon & Malus Domestica \\
\hline Grapes & Mangifera indica \\
\hline Apple &
\end{tabular}

\section{[C] Sample Preparation and Digestion:}

Vegetable samples were brought back to the laboratory and washed under clean tap water followed by double distilled water to eliminate soil and air-born pollutants. After removing the extra water from the surface of fruits and vegetables with the help of blotting papers, samples were cut into pieces packed in separate bags and kept in oven until a constant weight was achieved. The dried samples were grinded and passed through a sieved of $2 \mathrm{~mm}$ size and then kept at room temp for further analysis.

0.5 gram of dried sample was digested in microwave Digester $3000 \mathrm{SOLV}$ at 1400 watt for 3 hours in working solution of $\mathrm{H}_{2} \mathrm{SO}_{4}(65 \%), \mathrm{HClO}_{4}(65 \%)$ and $\mathrm{HNO}_{3}(70 \%)$ with ratio of 1:1:5 was prepare till the solution became transparent. The resulting solution was cooled and filtered with whatman filter paper. Finally volume of the extract was made up to $50 \mathrm{ml}$ using double distilled water.

\section{Analysis}

Concentration of heavy metals was carried out by using Atomic Absorption Spectrophotometer, (Thermo Scientific Pvt. Ltd. India Model No. AA 303) Double Beam and deuterium background hollow cathode lamps of $\mathrm{Fe}, \mathrm{Pb}, \mathrm{Cd}, \mathrm{Zn}, \mathrm{Cu}$ were used at specific wavelengths. All samples were run in triplicates.

\section{Result}

Table 1: Concentration of heavy metals $(\mathrm{mg} / \mathrm{kg}$ or $\mathrm{ppm})$ in vegetables.

\begin{tabular}{|l|l|l|l|l|l|}
\hline Commodity & $\mathrm{Cu}$ & $\mathrm{Cd}$ & $\mathrm{Fe}$ & $\mathrm{Co}$ & $\mathrm{Pb}$ \\
\hline Spinach & 0.32 & 0.27 & 16.83 & 5.32 & 0.26 \\
\hline Tomato & 0.511 & 0.77 & 8.427 & 2.245 & 0.2 \\
\hline Green pepper & 0.47 & 0.94 & 0.042 & 2.97 & 0.19 \\
\hline Lady finger & 0.14 & 0.02 & 11.4 & 1.49 & 0.32 \\
\hline Cauliflower & 0.6 & 0.2 & 9.65 & 5.75 & 0.92 \\
\hline
\end{tabular}

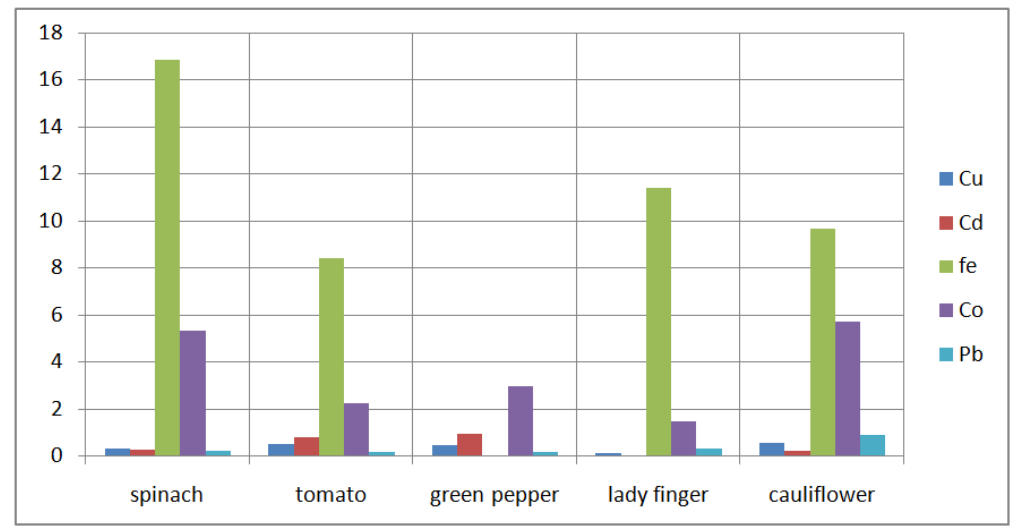

Figure 1: Represents the heavy metal concentration in the edible parts of five vegetables.

Table 2: Concentration of heavy metals $(\mathrm{mg} / \mathrm{kg}$ or $\mathrm{ppm})$ in fruits.

\begin{tabular}{|l|l|l|l|l|l|l|}
\hline Commodity & $\mathrm{Pb}$ & $\mathrm{Fe}$ & $\mathrm{Zn}$ & $\mathrm{Cu}$ & $\mathrm{Co}$ & $\mathrm{Cd}$ \\
\hline Water melon & 0.51 & 0.03 & 5.11 & 1.19 & 0.141 & 0.510 \\
\hline Grapes & 0.4 & 0.05 & 1.33 & 2.03 & 0.521 & 0.631 \\
\hline Apple & 0.2 & 0.06 & 2.34 & 1.5 & 0.43 & 1 \\
\hline mango & 1.824 & 0.362 & 0.635 & 3.186 & 0.56 & 5.143 \\
\hline
\end{tabular}




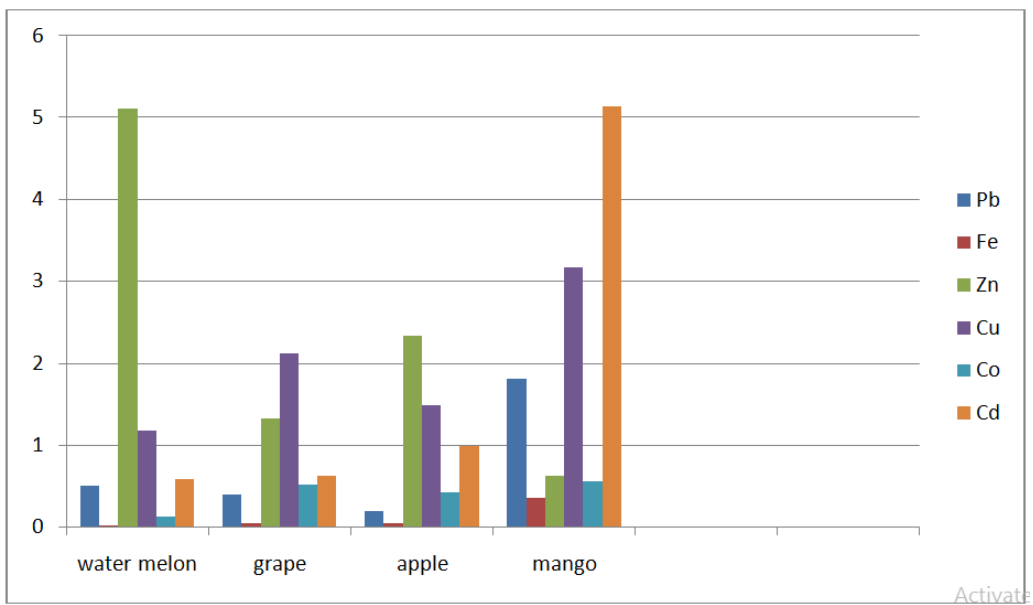

Figure 2: Represents the heavy metal concentration in the four different fruits.

The results of this study showed that the average concentration detected range from 0.2 to $5.75 \mathrm{mg} / \mathrm{kg}$ for given samples of fruits and vegetables. The highest mean of $\mathrm{Cd}, \mathrm{Fe}, \mathrm{Zn}, \mathrm{Cu}, \mathrm{Co}$, and $\mathrm{Pb}$ respectively. $\mathrm{Fe}$ concentration varied considerably in spinach, tomato, cauliflower and lady finger are crossed permissible limits. Copper concentration in cauliflower, spinach, apple, grapes are below than the safe limit. Overall, this study indicates that the vegetables and fruits sample are contaminated by toxic heavy metals. The level of these metals found in our study are compared with those reported for similar fruits and vegetables from some other part of the world.

\section{Conclusion}

From the given results it clears that $\mathrm{Fe}, \mathrm{Cu}, \mathrm{Cd}, \mathrm{Co}, \mathrm{Pb}, \mathrm{Zn}$ are present in the sample. These metals show toxic potential with injury to human health. The results of the present study showed that consumers are at great risk of purchasing fresh fruits and vegetables with this level of heavy metals beyond permissible limits as defined by the Indian Prevention of food Adulteration Act 1954.

\section{Acknowledegement}

I would like to express my deepest appreciation to all those who provided me the possibility to complete this research. A special gratitude to Dr. Manish Upadhaya, H.O.D. Chemistry department C.V. Raman University Kota, Bilaspur, Chhattisgarh whose contribution in stimulating suggestion and encouragement helped me to coordinate my project.

\section{References}

[1] Arora, M., Kiran, B., Rani, A., Kaur B. and Mittal, N. (2008) Heavy metal accumulation in vegetables irrigated with water from different sources. Food Chemistry, 111, 811-815. doi:10.1016/j.food chem. 2008.04.0 49

[2] Arora M. Wichelns, L.D., Raschid- sally P.G., Mc. Cornick, P.D., Bhari, A. and Minhas, P.S. “ The challenges of waste water irrigation in developing countries'. Agriculture water management 2008, 97:561-568.

[3] Ashraf R. and Ali T. A.., Effect of heavy metals on soil microbial community and mung bean seed and germination. Pakistan Journals of botany , 39(2), 629-636 (2007)

[4] Awasthi S K (2000). Prevention of food adulteration act No.37 of 1954. Central and state rule as amended of 1993. ${ }^{\text {rd }}$ Edition. Ashoka Law House, New Delhi

[5] Divkli, U., Horzum, N., Soylak, M. and Elci, L. 2006. Trace heavy metal content of some spices and herbal plants from western Anatolia, Turkey. International Journal of food Science and Technology 41: 712- 716.

[6] D' Mello, J.P.G. 2003. Food safety: contaminants and toxins, Scottish Agricultural college, Edinburgh, UK, 480 pages.

[7] D'Mello, J.P.G., 2003. Food Safety: Contaminants and toxins. CABI Publishing, Wallinford, Oxon, UK, Cambridge, MA, p. 480

[8] Environmental Protection Agency, Toxicological review of trivalent chromium (CAS no. 16065-83-1) in support of summary information on the integrated risk information system (IRIS), US Environmental Protection Agency, Washington, DC, 1998.

[9] FAO/WHO, "Evaluation of certain food additives and Contaminants. Geneva, World Health Organization, Joint FAO/WHO Expert committee on Food Additives, World Health Organization Technical Report Series, "vol 859, pp.29-35, 1995

[10] Guala S.D., Vega F.A. AND Covelo E.F., The dynamics of heavy metals in plant soil interactions. Ecological Modelling, 221, $1148-1152(2009)$

[11] M. A. Radwan, and A.K. Salama, " Market basket survey for some heavy metals in Egyptian fruits and vegetables,' Food and Chemical Toxicology, vol. 44, no. 8, pp. 1273-1278, 2006.

[12] Najat k. Mohammed, fatma O. Khamis " Assessment of heavy metal contamination in vegetables consumed in Zanzibar vol. 4 No. 8588-594 (2012).

[13] Perveen S., Ihsanullah I., Study of accumulation of heavy metals in vegetables Receiving Sewage Water J. Chem. Soc. Pak., Vol 33, No. 2, 2011 page 220-227

[14] Ramesh H.L. and Yogananda Moorthy V.N. Assessment of Heavy Metal contamination in Green Leafy Vegetables Grown in Bangalore Urban District of Karnataka. Advances in Life Science and Technology Vol. 6, 2012 
[15] Sobukola, O.P., Adeniran, O.M.,Odedairo, A.A. \& Kajihausa, O.E. (2010). Heavy metal level of some fruits and leafy vegetables from selected , markets in Lagos, Nigeria. Afr.J. Food Sci., 4(2): 389-393.

[16] Thompson, H.C. and Kelly, W.C. 1990. Vegetable Crops. $5^{\text {th }}$ Edn., McGraw Hill Publishing Company Ltd., New Delhi.

[17] Uwah E.I., Ndahi N.P. and Ogugbuaja V.O , 2009. Study of the levels of some Agricultural Pollutants in Soils, and Water Leaf "(Talinum Triangulare) obtained in maiduguri, Nigeria. Journal of Applied Science in Environmental Sanitation.(221)

[18] WHO. 1992. Cadmium, Environmental Health Criteria, Geneva Vol. 134.

[19] WHO. 1995. Lead. Environmental Health Criteria, Geneva, Vol. 165

[20] Zhou, H.; Zeng, M; Zhou, X.;Liao, B.; Liu, J.; Lei, M.; Zhong, Q; Zeng, H. Assessment of heavy metal contamination and bioaccumulation in soyabean plants from mining and smelting area of southern human province, china. Environ. Toxicol. Chem.. 2013, 32, 2719-2727. 